\title{
Physicochemical Properties of Honeys Produced in North-West of Algeria
}

\author{
Samira Nair ${ }^{*}$ and Nebia Bouzidi Maghraoui ${ }^{1}$ \\ ${ }^{1}$ Geo-environment and Development Researches laboratory, University Mustapha Stambouli University of \\ Mascara, Algeria. \\ Email: falati22@yahoo.fr; n-samira@hotmail.com
}

\begin{abstract}
Honey is a nutritious product that is produced by honey bees. Its composition depends highly on the type of flowers utilised by the bee as well as the climatic conditions. This study was intended to evaluate the quality parameters of ten honey samples, from various regions in NorthWest of Algeria. The physicochemical property of the honeys [moisture, electrical conductivity, hydroxymethylfurfural, $\mathrm{pH}$, acidity (free, total and lactone), reducing sugars, apparent sucrose, insoluble material, ash, and diastase activity] was determined. The moisture shows values of $14.21 \pm 0.18 \%$ and $16.59 \pm 0.12 \%$. The water insoluble material content ranged between $0.01 \pm 0.03$ to $0.67 \pm 0.07 \%$. The reducing sugars were between $66.3 \pm 0.37$ and $88 \pm 0.23 \%$, mean percentages of apparent sucrose were $6.54 \pm 0.23 \%$. Honey samples showed an appropriate diastase number with an average of $12.35 \pm 0.24$, and their HMF (hydroxymethylfurfural) content ranging from $5.65 \pm 0.37$ to $37.42 \pm 0.55 \mathrm{mg} / \mathrm{kg}$, Conductivity values ranged from $10 \pm 0.54$ to $606 \pm 2.45 \mathrm{\mu S} / \mathrm{cm}$. The ash content ranged from $0.019 \pm 0.01 \%$ to $0.37 \pm 0.05 \%$. All honeys were acidic, having a $\mathrm{pH}$ in the range $3.7 \pm 0.03-4.78 \pm 0.05$. The average values for free acidity in samples were between $10 \pm 0.22$ and $25 \pm 0.5 \mathrm{meq} / \mathrm{kg}$. Lactonic acidity ranges were from $2 \pm 0.15$ to $5 \pm 0.15 \mathrm{meq} / \mathrm{kg}$. Total acidity ranged from $12 \pm 0.37$ to $30 \pm 0.65 \mathrm{meq} / \mathrm{kg}$. All the samples were found to meet all major national and international honey specifications.
\end{abstract}

Keywords: Algerian honey; quality parameters; physicochemical properties.

\section{Introduction}

Codex Alimentarius Commission [1] defines honey as "Honey is the natural sweet substance produced by honey bees from the nectar of plants or from honey dew".

Different kinds of bee honey vary considerably in their physical, chemical and organoleptic properties so the composition of honey is rather variable, depending on its geographical floral origin, season and other external factors, such as environmental factors and treatment of beekeepers [2].

Honey consists essentially of sugars, predominantly fructose (40-50\%) and glucose (32-37\%), small amounts of sucrose $(<2 \%)$ and mineral constituents (ash less than $0.1 \%)$. Honey also contains water (13-20\%), other substances such as organic acids, enzymes vitamins in small amounts trace elements (Fe, $\mathrm{Cu}, \mathrm{Zn}, \mathrm{Sn}$, etc.), and solid particles, mainly consisting of pollen [3].

Algeria has wealthy biodiversity because of its geophysical characteristics and climate. Owing to these varied ecological conditions, the country is home to some of the most diverse flora in Africa. This diversity makes it highly suitable for sustaining a large number of bee colonies. The floral biodiversity of the country is of great importance to honey production. The apiculture in Algeria is widely practiced in the mountainous region (Kabylie, Aurès mountains), in the coastal plains (Mitidja), in the interior plains (Mascara), and in the valleys of large wadis (Soummam), the deserted areas of the highlands and the southern region of the country being the only exceptions to honey production [4].

In Algeria, honey is widely used in traditional medicine; however, studies that estimate Algerian honey quality parameters are approximately absent. To ensure the authenticity of the honey, it is required to perform extensive honey compositional analyses [5].

In order to produce and improve the quality of honey to meet the demands of international markets and quality criteria [1], information about the quality of honey produced in the area is important. 
The aim of the present work was to determinate the quality of Algerian honey in terms of physicochemical properties, and verify their compliance with international standards.

\section{Materials and Methods}

\subsection{Sample Collection}

Ten samples $(500 \mathrm{~g})$ of honeys produced in North-West of Algeria were collected from beekeepers, the samples were stored in a refrigerator in airtight plastic containers until analysis.

\subsection{Physicochemical Analysis}

\subsubsection{Water Content}

The water content was determined by measuring the reactive index (R.I) using a refractometer at $20^{\circ} \mathrm{C}$ according to the honey method [6]. The percentage (\%) of water was determined using the Chataway table that relates the $\%$ of water with the R.I. The experimental results were expressed as grams of water for 100 grams of honey $(\mathrm{g} / 100 \mathrm{~g})$.

\subsubsection{HMF}

The determination of hydroxylmethylfufural in honey was based on the original method of Winkler [6]. To aliquot parts of a honey solution, solutions of p-toluidine and barbituric acid were added and the resultant colour was measured against a blank in $1 \mathrm{~cm}$ cuvettes at $550 \mathrm{~nm}$.

\subsubsection{Determination of Apparent Reducing Sugars and Apparent Sucrose}

Apparent reducing sugars are defined as the sugars that reduce a Fehling's solution under specified conditions. Reducing sugar content is determined by titration of a modified Fehling's solution at its boiling point against a solution of honey. Methylene blue is used as the internal indicator. The apparent sucrose content is calculated by multiplying difference of percent invert sugar values by 0.95 and expressed as grams, apparent sucrose per 100 g honey $[7 ; 6]$.

\subsubsection{Diastase Number}

The diastase number (DN), was determined spectrophometrically according to the Schade method [8]. The diastase activity unit is defined as the amount of enzyme which converts $0.01 \mathrm{~g}$ of starch (g) during $1 \mathrm{~h}$ at $40^{\circ} \mathrm{C}$ per $1 \mathrm{~g}$ of honey. A standard solution of starch capable of developing with iodine, a color in a defined range of intensity, is acted upon by the enzyme in a sample under standard conditions. The diminution in the blue color is measured at time intervals. A plot of absorbance against time, or a regression equation, is used to determine the time (tx) required to reach the specified absorbance, 0.235. DN is calculated as 300 divided by tx [8].

\subsubsection{Determination of pH, Free Acidity, Lactones and Total Acidity}

The $\mathrm{pH}$ is measured on a $10 \%$ honey solution. The free acidity is obtained by plotting the neutralization curve with a sodium hydroxide solution and determining the $\mathrm{pH}$ of the equivalence point $(\mathrm{pHe})$. The acidity of the lactones is obtained by adding an excess of sodium hydroxide to the honey solution and plotting the neutralization curve of the excess sodium hydroxide by a back titration with sulphuric acid [6].

\subsubsection{Determination of Insoluble Matter}

The insoluble matter is collected on a crucible of specified pore size and the dried residue is weighed after being washed free of soluble material [9].

\subsubsection{Determination of Ash Content}

The honey is ashed at a temperature no higher than $600^{\circ} \mathrm{C}$ and the residue weighed $[1,6]$.

\subsection{Statistical Analysis}

Statistical analysis was performed using Excel software; all the experiments were operated in triplicate. Values are expressed as mean \pm standard deviation. 


\section{Result and Discussion}

The measured values of physicochemical properties of honeys are shown in Table 1 . Water content, a parameter related to the maturity degree, was between $14.21 \pm 0.18 \%$ and $16.59 \pm 0.12 \%$, indicating optimum harvesting and a good degree of maturity. The moisture contents in our samples are in the range with those reported by 10 makhloufi et al. and chefrour et al. [10; 11]. Ouchemoukh et al. found in 11 honeys samples from Bejaia (Algeria) values from 14.6 to $19 \%$ [12].

Nanda et al. stated that moisture content is affected by climate and moisture content of original plant [13]. The water content was also influenced by the time of extraction from the comb in relation to ripening process by the bees. The values obtained were all below 20\%, which is the maximum allowed by the European Union Directive [14].

Water insoluble solids, represents suspended wax particles, and/or insect and vegetable debris in honey. The water insoluble material content of the honey samples ranged between $0.01 \pm 0.03$ to $0.67 \pm$ $0.07 \%$. The maximum values were found for the samples S2, S5, and S10. According to Codex Alimentarius [9], the maximum amount should be below 0.1\%. Rebiai et al. (2015) mentioned 0.1-0.19 \% range of Water Insoluble solids content in the honeys from different regions of South Algeria [15].

The major sugars present in honey are fructose and glucose. The reducing sugars (Table 1) were between $66.3 \pm 0.37$ and $88 \pm 0.23 \%$. This is above $65 \%$ the minimum limit set by EC regulations [14] in all samples. Makhloufi et al. reported Algerian honey with 55.20 to $84.30 \%$ reducing sugars [10]. Ouchemoukh et al. also reported high reducing sugars of $77.75 \%$ in 11 Algerian honeys [12].

The mean percentages of apparent sucrose (Table 1) were $6.54 \pm 0.23 \%$. According to Makhloufi et al. the amount of sucrose from Algerian honeys is between 0 and $4.3 \%$ [10].

All samples were below 10\%, which is the maximum legal limit set by Bocquet [16]. These two parameters confirm that the honey samples studied were floral honeys [17]. These results confirm that sugars represent the major constituents of honey.

Honey samples showed an appropriate diastase number with an average of $12.35 \pm 0.24$. Our results coincide with those reported by makhloufi et al.[18]. HMF (hydroxymethylfurfural) content of different honey samples range from $5.65 \pm 0.37$ to $37.42 \pm 0.55 \mathrm{mg} / \mathrm{kg}$ (Table 1). Makhloufi et al., BenazizaBouchema and Schweitzer have reported that HMF values were between 0 and $598.8 \mathrm{mg} / \mathrm{kg}$ in 140 Algerian honeys [10, 19].

Thus, all samples fell within the European Community regulations [14] and presented a high degree of freshness. (Indicate the recommendations for these parameters from codex - diastase above 8, HMF max 80)

Electrical conductivity varies with botanical origin [20]; the international standards prescribe a maximum limit of $800 \mathrm{\mu S} / \mathrm{cm}$ for most nectar honeys [1, 14 and 21]. Conductivity values ranged from 10 \pm 0.54 to $606 \pm 2.45 \mu \mathrm{S} / \mathrm{cm}$, as all samples had conductivity measurements below $800 \mu \mathrm{S} / \mathrm{cm}$; this again suggests that honeys collected in this work were of floral origin. Ouchemoukh et al. mentioned 0.21 1.61 MS/cm range of Electrical conductivity in the honey from different regions of Bejaia (Algeria) [12].

The ash content of the studied honey samples differs widely. It ranged from $0.019 \pm 0.01 \%$ to $0.37 \pm$ $0.05 \%$. These differences in mineral content are dependent on the type of soil in which the original nectar bearing plant was located [22]. Ash values were below $0.6 \%$ in all cases, as expected for nectar honeys $[1,14]$. Similar findings were reported by Ouchemoukh et al. [12].

The ash content is mainly determined by soil and clime characteristics. Downey et al. have previously reported the existence of a linear relationship between ash content and electrical conductivity of honeys [23]. Confirmation of this relationship, in the Algeria honeys analyzed, is revealed following linear regression analysis of these two variables. This regression is shown graphically in Figure 1.

Table 1. Results of physicochemical analyses of honey samples

\begin{tabular}{|c|c|c|c|c|c|c|c|c|c|c|c|c|}
\hline $\begin{array}{l}\text { Sam } \\
\text { ples }\end{array}$ & $\begin{array}{c}\text { Moist } \\
\text { ure } \\
(\%)\end{array}$ & $\begin{array}{c}\text { Insolu } \\
\text { ble } \\
\text { materi } \\
\text { al } \\
\text { (g/100 }\end{array}$ & \begin{tabular}{|c} 
Reduci \\
ng \\
sugars \\
$(\%)$
\end{tabular} & $\begin{array}{c}\text { Appar } \\
\text { ent } \\
\text { sucros } \\
\text { e }(\%)\end{array}$ & $\begin{array}{c}\mathrm{HMF} \\
(\mathrm{mg} / \mathrm{k} \\
\mathrm{g})\end{array}$ & $\begin{array}{c}\text { Diast } \\
\text { ase } \\
\text { numb } \\
\text { er }\end{array}$ & $\begin{array}{c}\text { Electric } \\
\text { al } \\
\text { conduct } \\
\text { ivity } \\
\left(\mu \mathrm{S} . \mathrm{cm}^{-}\right.\end{array}$ & $\begin{array}{l}\text { Ash } \\
(\%)\end{array}$ & $\mathrm{pH}$ & \begin{tabular}{|c|} 
Free \\
acidit \\
$\mathrm{y}$ \\
$(\mathrm{meq} /$ \\
$\mathrm{kg})$
\end{tabular} & \begin{tabular}{|c} 
Lacto \\
ne \\
acidit \\
$y$ \\
$(\mathrm{meq} /$
\end{tabular} & $\begin{array}{c}\text { Total } \\
\text { acidit } \\
y \\
(\mathrm{meq} \\
/ \mathrm{kg})\end{array}$ \\
\hline
\end{tabular}




\begin{tabular}{|c|c|c|c|c|c|c|c|c|c|c|c|c|}
\hline & & g) & & & & & 1) & & & & $\mathrm{kg})$ & \\
\hline S1 & $\begin{array}{c}14.25 \pm \\
0.56 \\
\end{array}$ & $\begin{array}{c}0.0103 \pm \\
0.03\end{array}$ & $\begin{array}{c}76.41 \pm 0 \\
.31 \\
\end{array}$ & $\begin{array}{c}6.4 \pm 0 . \\
15 \\
\end{array}$ & $\begin{array}{c}8.94 \pm 0 . \\
24 \\
\end{array}$ & $\begin{array}{c}12.2 \pm 0 \\
.35 \\
\end{array}$ & $10 \pm 0.54$ & $\begin{array}{c}0.019 \pm 0 \\
.01 \\
\end{array}$ & $\begin{array}{c}3.85 \pm 0 \\
.09 \\
\end{array}$ & $\begin{array}{c}16 \pm 0.6 \\
1 \\
\end{array}$ & $\begin{array}{c}3.2 \pm 0 . \\
45\end{array}$ & $\begin{array}{c}19.2 \pm \\
1.06 \\
\end{array}$ \\
\hline $\mathrm{S} 2$ & $\begin{array}{c}15.56 \pm \\
0.67\end{array}$ & $\begin{array}{c}0.67 \pm 0 . \\
07\end{array}$ & $\begin{array}{c}75.65 \pm 0 \\
.22\end{array}$ & $\begin{array}{c}5.2 \pm 0 . \\
23\end{array}$ & $\begin{array}{c}7.48 \pm 0 \\
12\end{array}$ & $\begin{array}{c}9.3 \pm 0 . \\
21\end{array}$ & $24 \pm 0.67$ & $\begin{array}{c}0.079 \pm 0 \\
.03\end{array}$ & $\begin{array}{c}3.7 \pm 0 . \\
03\end{array}$ & $\begin{array}{c}10 \pm 0.2 \\
2\end{array}$ & $2 \pm 0.15$ & $\begin{array}{c}12 \pm 0 . \\
37\end{array}$ \\
\hline S3 & $\begin{array}{c}14.45 \pm \\
0.23\end{array}$ & $\begin{array}{c}0.014 \pm 0 \\
.01\end{array}$ & $\begin{array}{c}67.42 \pm 0 \\
.18\end{array}$ & $\begin{array}{c}9.38 \pm 0 \\
.5\end{array}$ & $\begin{array}{c}17.92 \pm \\
0.5\end{array}$ & $\begin{array}{c}16.5 \pm 0 \\
.13\end{array}$ & $21 \pm 0.52$ & $\begin{array}{c}0.06 \pm 0 \\
02\end{array}$ & $\begin{array}{c}4.78 \pm 0 \\
.05\end{array}$ & $\begin{array}{c}13 \pm 0.1 \\
0\end{array}$ & $\begin{array}{c}2.6 \pm 0 . \\
32\end{array}$ & $\begin{array}{c}15.6 \pm \\
0.42\end{array}$ \\
\hline $\mathrm{S} 4$ & $\begin{array}{c}14.8 \pm 0 \\
.36 \\
\end{array}$ & $\begin{array}{c}0.04 \pm 0 . \\
03\end{array}$ & $88 \pm 0.23$ & $\begin{array}{c}9.03 \pm 0 \\
.26 \\
\end{array}$ & $\begin{array}{c}22.45 \pm \\
0.18 \\
\end{array}$ & $\begin{array}{c}12 \pm 0.4 \\
7 \\
\end{array}$ & $117 \pm 1.05$ & $\begin{array}{c}0.18 \pm 0 . \\
01\end{array}$ & $\begin{array}{c}4.55 \pm 0 \\
.05 \\
\end{array}$ & $20 \pm 0.5$ & $\begin{array}{c}4.2 \pm 0 . \\
12\end{array}$ & $\begin{array}{c}24.2 \pm \\
0.62 \\
\end{array}$ \\
\hline S5 & $\begin{array}{c}15.75 \pm \\
0.20\end{array}$ & $\begin{array}{c}0.46 \pm 0 . \\
05\end{array}$ & $\begin{array}{c}75.29 \pm 0 \\
.41\end{array}$ & $\begin{array}{c}2.97 \pm 0 \\
.10\end{array}$ & $\begin{array}{c}5.65 \pm 0 . \\
37\end{array}$ & $\begin{array}{c}12.6 \pm 0 \\
.24\end{array}$ & $308 \pm 1.12$ & $\begin{array}{c}0.2 \pm 0.0 \\
5\end{array}$ & $\begin{array}{c}4.16 \pm 0 \\
.02\end{array}$ & $\begin{array}{c}24 \pm 0.1 \\
8\end{array}$ & $\begin{array}{c}4.8 \pm 0 . \\
21\end{array}$ & $\begin{array}{c}28.8 \pm \\
0.39\end{array}$ \\
\hline S6 & $\begin{array}{c}15.8 \pm 0 \\
.15\end{array}$ & $\begin{array}{c}0.024 \pm 0 \\
.01\end{array}$ & $\begin{array}{c}66.33 \pm 0 \\
.37\end{array}$ & $\begin{array}{c}6.3 \pm 0 . \\
13\end{array}$ & $\begin{array}{c}26.83 \pm \\
0.45\end{array}$ & $\begin{array}{c}11.36 \pm \\
0.54\end{array}$ & $31 \pm 0.63$ & $\begin{array}{c}0.08 \pm 0 \\
03\end{array}$ & $\begin{array}{c}4.61 \pm 0 \\
.02\end{array}$ & $\begin{array}{c}12 \pm 0.3 \\
2\end{array}$ & $\begin{array}{c}2.4 \pm 0 . \\
10\end{array}$ & $\begin{array}{c}14.4 \pm \\
0.42\end{array}$ \\
\hline S7 & \begin{tabular}{|c|}
$16.59 \pm$ \\
0.12 \\
\end{tabular} & $\begin{array}{c}0.032 \pm 0 \\
.02 \\
\end{array}$ & $\begin{array}{c}67.23 \pm 0 \\
.5 \\
\end{array}$ & \begin{tabular}{|c|}
$6.13 \pm 0$ \\
.48 \\
\end{tabular} & $\begin{array}{c}22.43 \pm \\
0.22 \\
\end{array}$ & $\begin{array}{c}16.2 \pm 0 \\
.10 \\
\end{array}$ & $333 \pm 1.55$ & $\begin{array}{c}0.32 \pm 0 \\
02\end{array}$ & \begin{tabular}{|c|}
$3.72 \pm 0$ \\
.03 \\
\end{tabular} & $25 \pm 0.5$ & $5 \pm 0.15$ & $\begin{array}{c}30 \pm 0 . \\
65 \\
\end{array}$ \\
\hline S8 & $\begin{array}{c}16.33 \pm \\
0.25 \\
\end{array}$ & $\begin{array}{c}0.035 \pm 0 \\
.04 \\
\end{array}$ & $\begin{array}{c}71.36 \pm 0 \\
.25 \\
\end{array}$ & $\begin{array}{c}9.65 \pm 0 \\
.21 \\
\end{array}$ & $\begin{array}{c}26.19 \pm \\
0.12 \\
\end{array}$ & $\begin{array}{c}18.07 \pm \\
0.13 \\
\end{array}$ & $90 \pm 0.45$ & $\begin{array}{c}0.1 \pm 0.0 \\
3 \\
\end{array}$ & $\begin{array}{c}3.73 \pm 0 \\
.03 \\
\end{array}$ & $\begin{array}{c}10 \pm 0.2 \\
2 \\
\end{array}$ & $\begin{array}{c}2.1 \pm 0 . \\
10 \\
\end{array}$ & $\begin{array}{c}12.1 \pm \\
0.32 \\
\end{array}$ \\
\hline S9 & \begin{tabular}{|c|}
$14.21 \pm$ \\
0.18 \\
\end{tabular} & $\begin{array}{c}0.04 \pm 0 . \\
06\end{array}$ & $\begin{array}{c}69.58 \pm 0 \\
.31 \\
\end{array}$ & $\begin{array}{c}8.37 \pm 0 \\
.10 \\
\end{array}$ & $\begin{array}{c}37.42 \pm \\
0.55 \\
\end{array}$ & $\begin{array}{c}13.04 \pm \\
0.10 \\
\end{array}$ & $18 \pm 0.14$ & \begin{tabular}{|c}
$0.04 \pm 0$. \\
02 \\
\end{tabular} & \begin{tabular}{|c|}
$4.27 \pm 0$ \\
.05 \\
\end{tabular} & \begin{tabular}{|c|}
$20 \pm 0.4$ \\
5 \\
\end{tabular} & $4 \pm 0.12$ & $\begin{array}{c}24 \pm 0 . \\
57 \\
\end{array}$ \\
\hline S10 & \begin{tabular}{|c|}
$15.21 \pm$ \\
0.54 \\
\end{tabular} & $\begin{array}{c}0.32 \pm 0 . \\
01\end{array}$ & $\begin{array}{c}78.66 \pm 0 \\
.40\end{array}$ & $\begin{array}{c}8.94 \pm 0 \\
.14 \\
\end{array}$ & $\begin{array}{c}14.97 \pm \\
0.42 \\
\end{array}$ & $\begin{array}{c}13.63 \pm \\
0.20 \\
\end{array}$ & $606 \pm 2.45$ & $\begin{array}{c}0.37 \pm 0 . \\
05\end{array}$ & \begin{tabular}{|c|}
$4.11 \pm 0$ \\
.02 \\
\end{tabular} & $\begin{array}{c}15 \pm 0.2 \\
0 \\
\end{array}$ & $3 \pm 0.13$ & $\begin{array}{c}18 \pm 0 . \\
23\end{array}$ \\
\hline
\end{tabular}

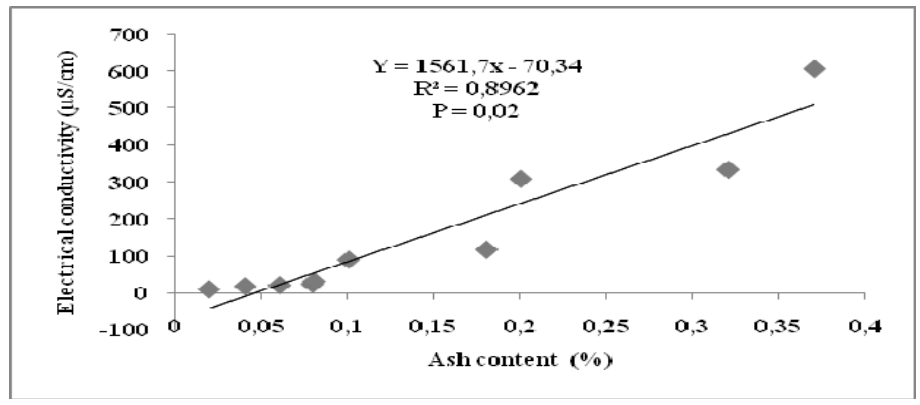

Figure 1. Relationship between Ash content and electrical conductivity

All honeys were acidic, having a $\mathrm{pH}$ in the range $3.7 \pm 0.03$ to $4.78 \pm 0.05$. The $\mathrm{pH}$ of honeydew and blossom honey blends should be between 3.5 and 4.5. The $\mathrm{pH}$ of honeydew honey should be between 4.5 and 5.5 [24]. These $\mathrm{pH}$ values indicate that the honeys tested were most likely of floral origin. These results agreed with data reported by Ouchemoukh et al. [12].

Acidity in honey is calculated as free, lactonic and total acidity. European Commission specifies a free acidity of not more than 50 milli-equivalents acid per $1000 \mathrm{~g}$ (meq/kg) [14]. The average values for free acidity in samples were between $10 \pm 0.22$ and $25 \pm 0.5 \mathrm{meq} / \mathrm{kg}$. Free acidity was, likewise, within limits (below $50 \mathrm{meq} / \mathrm{kg}$ ) indicating an absence of undesirable fermentations. Lactonic acidity ranges were from $2 \pm 0.15$ to $5 \pm 0.15 \mathrm{meq} / \mathrm{kg}$. Total acidity ranged from $12 \pm 0.37$ to $30 \pm 0.65 \mathrm{meq} / \mathrm{kg}$; Our results are quite in agreement with Ouchemoukh et al.[12]. Rebiai et al. reported very high values of free acidity with an average of $39.82 \pm 16.03 \mathrm{meq} / \mathrm{kg}[15]$.

\section{Conclusion}

The studies of the physico-chemical properties of honey are important for the certification process that determines honey quality. In this study, the physicochemical property of honeys collected from different regions in north-west of Algeria was investigated. This research concludes that the samples were found 
to meet all major national and international honey specifications and that they were generally of floral origin. All parameters measured indicate that the Algerian honeys were generally of floral origin.

\section{References}

1. Codex Alimentarius Commission, "Codex standard 12, Revised Codex Standard for Honey," Standards and Standard Methods, vol. 11, 2001.

2. A.A.E. EL-Metwally, "Factors Affecting the Physical and Chemical Characteristics of Egyptian Beehoney", Ph. D. Thesis, Fac. Agric. Cairo Univ, 320 p, 2015.

3. M. Alvarez-Suarez, Jose, Giampieri, Francesca, Battino and Maurizio, "Honey as a Source of Dietary Antioxidants: Structures, Bioavailability and Evidence of Protective Effects Against Human Chronic Diseases," Current Medicinal Chemistry, vol. 20, no. 5, pp. 621-638, February 2013.

4. M.H. Hussein, "Beekeeping in Africa: I- North, East, North-east and West African countries", Plant Protection Dept., Faculty of Agriculture, Assiut University, Assiut, EGYPTE. Apiacta, vol. 1, pp. 34-48, 2001.

5. S. Serrano, M. Villarejo, R. Espejo and M. Jodral, "Chemical and physical parameters of Andalusian honey: classification of Citrus and Eucalyptus honeys by discriminant analysis", Food Chem, vol. 87, pp. 619-625, 2004.

6. S. Bogdanov, "Harmonized methods of the International Honey Commission. International Honey Commission", International Honey Commission, pp. 1-61, 2009.

7. S. Bogdanov, P. Martin, C. Lüllmann, "Harmonised methods of the European Honey Commission", Apidologie, 28, extra issue, pp. 1-59, 1997.

8. J.E. Schade, G.L. Marsh, J.E. Eckert, "Diastatic activity and hydroxymethylfurfural in honey and their usefulness in detecting heat adulteration", Food Research, 23, pp. 446-463, 1958.

9. D.W. Lord, M. J. Scotter, A.D. Whittaker and R.Wood, "The determination of acidity, apparent reducing sugar and sucrose, hydroxymethylfurfural, mineral, moisture, water insoluble solids contents in honey; collaborative study", J.Assoc. Publ. Anal. (UK), 26, pp. 51-76, 1988.

10.C. Makhloufi, D. Kerkvliet, G. Ricciardelli d'albore, A. Choukri, R. Samar, "Characterization of Algerian honeys by palynological and physico-chemical methods", Apidologie, 41, 509-521, 2010.

11.A. Chefrour, M.J. Battesti, K. Ait, A.Tahar, "Melissopalynologic and physicochemical analysis of some northeast Algerian honeys", Eur. J. Sci. Res, 18, pp. 389-401, 2007.

12.S.Ouchemoukh, H.Louaileche and P. Schweitzer, "Physicochemical characteristics and pollen spectrum of some Algerian honeys", Food Control, vol. 18, pp. 52-58, 2007.

13.V. Nanda, B.C. Sarkar, H. K. Sharma and A. S. Bawa, "Physicochemical properties and estimation of mineral content in honey produced from different plants in Northern India", Journal of Food Composition and Analysis, vol. 16, pp. 613-619, 2003.

14.European Commission, "Council Directive 2001/110/EC of 20 December 2001 relating to honey", Official Journal of the European Communities L10, 47-52, 2002.

15.A. Rebiai, T. Lanez, A. Chouikh, "Physicochemical and biochemical properties of honey bee products in south Algeria", Scientific Study \& Research, 16(2), pp. 133-142, 2015.

16.M. Bocquet, "Flora mellifera: the Lavender - FT 4112 (sheets 711 to 714) ", OPIDA, vol. 20, no. 83, p. 4, 1993.

17.P.B. Andrade, M.T. Amaral, P.Isabel, J. Carvalho, R.Seabra and A. Cunha, "Physicochemical attributes and pollen spectrum of Portuguese heather honeys", Food Chemistry, vol. 66, pp. 503-510, 1996.

18.C. Makhloufi, P. Schweizer, C. Azouzi, L. Persano Oddo, A. Choukri, L. Hocine, G. Ricciardelli D'Albore, "Some properties of Algerian honey", Apiacta, 42, 73-80, 2007.

19.D. Benaziza-Bouchema, P. Schweitzer, "Characterization of the main honeys from the northern regions of Algeria". Cah Agric, vol. 19, No. 6, 2010.

20.A. Terrab, M.J. Diez and F.J. Heredia, "Palynoloical, physico-chemical and colour characterization of Moroccan honeys: I. River red gum (Eucalyptus camaldulensis Dehnh) honey", Int. J. Food Sci. Technol, vol. 38, pp. 379386, 2003.

21.S. Bogdanov, C. Lüllmann, P. Martin, W. Von Der Ohe, H. Russmann, G. Vorwohl, L. Persano Oddo, A.G. Sabatini, G.L. Marcazzan, R. Piro, C. Flamini, M. Morlot, J. Lheritier, R. Borneck, P. Marioleas, A. Tsigouri, J. Kerkvliet, A. Ortiz Valbuena, T. Ivanov, B. D’Arcy, B. Mossel and P.Vit, "Honey quality, methods of analysis 
and international regulatory Standards: review of the work of the International Honey Commission", Bee World, vol. 80, pp. 61-69, 1999.

22.E. Anklam, "A review of analytical methods to determine the geographical and botanical origin of honey", Food Chemistry, vol. 63, pp. 549-562, 1998.

23.G. Downey, K. Hussey, J. Daniel Kelly, T. F.Walshe, and P. G. Martin, "Preliminary contribution to the characterization of artisanal honey produced on the island of Ireland by paleontological and physico-chemical data", Food Chemistry, vol. 91, pp. 347-354, 2005.

24.M.Gonnet, "Analysis of honeys. Description of some quality control methods", Bul. Tech. Apic, vol. 54, no. 13 (1), pp. 17-36, 1986. 